okresu jebuzejskiego, a kończąc na czasach Sulimana Wspaniałego. Należy jeszcze dodać, że właściwie były to pierwsze badania na terenie Swiętego Miasta, podczas których konsekwentnie zastosowano ścisłą analizę form ceramicznych oraz stratygraficzną metodę datowania znalezisk. Studia nad ceramiką palestyńską zostały w ostatnich latach posunięte daleko naprzód dzięki wysiłkowi m. in. R. A m i r a n, K. K e n y o n i.P. L a p p a. Dlatego podawane powyżej przypuszczalnie datowania najprawdopodobniej nie ulegną zmianie, a co najwyżej uściśleniu.

Kraków

ZDZISEAW KAPERA

\title{
DOKUMENT HISTORYCZNY O NAZARET
}

W krytycznych ocenach ewangelii często spotykano wzmiankę, że istnienie miasta Nazaret $w$ epoce Nowego Testamentu nie jest historycznie udokumentowane, że wobec tego ono wówczas nie istniało. Stąd wysnuwano dalszy wniosek, że opowiadanie ewangelii o zamieszkaniu P. Jezusa wraz z rodzicami tamże jest legendą później utworzoną. A zwolennicy Drewsa i Smitha jeszcze dalej poszli twierdząc, że Pan Jezus w ogóle nie istniał.

W ostatnich 10.latach tego zarzutu już się nie podnosi, gdyż spokojne, neutralne i obiektywne badania tekstów ewangelicznych a limine odrzucają taką interpretację. Ostatnio przybył nowy dokument, o którym wspomnieliśmy przed rokiem, stwierdzający bezpodstawność hipotezy ultrakrytyków. Ekipa archeologów pod przewodnictwem Uniwersytetu jerozolimskiego znalazła w Cezarei, głośnej siedzibie prokuratorów rzymskich, fragmenty tablicy marmurowej wyliczającej oddziały kapłanów żydowskich rozproszonych po zbụrzeniu Jerozolimy w r. 70. Tekst odczytał, uzupełnił i zrekonstruował prof. M. Avi-J o nah i ogłosił w czasopiśmie Israel Exploration Journal (pt. A list of Priestly courses from Caesarea). Z rekonstrukcji, trudnej a umiejętnie przeprowadzonej, wynika, że na tablicy kamiennej zestawiono w oparciu o I Kron 24, 7-18 poszczególne 24 oddziały kapłanów dodając przy każdym miejscowość, w której znalazł schronienie po roku 70 . Na podobne zestawienie, oddziałów kảpłańskich zwrócił już uwagę prof. $\mathrm{D}$ alman $\mathrm{m}$ dziele: Orte und Wege Jesu z r. 1924. Wspomniał on o poecie żydowskim z VII czy VIII wieku po Chr., który w ,lamentacji” wspomina pełen żalu, że „oddział nazaretański (miszmeret nacrat), wypędzony został aż do bram (granic) kraju”.

Z tablicy znalezionej ostatnio w Cezarei zachowały się tylko 3 maleńkie ułamki z kilkudziesięciu literami, które jednak wystarczyły, by tablicę językowo zrekonstruować. Wiersz, który nas bliżej obchodzi, brzmi w rekonstrukcji:

„Oddział osiemnasty Happiceca Nacaret”, a z niego zachowały się tylko ostatnie litery: $(n)-c-r-t, z$ litery pierwszej $n$ odczytać można tylko część dolną. Jednakże rekonstrukcja dalszych liter wiersza i dalszych fragmentów nie ulega wątpliwości, gdyż jest zagwarantowana i Kron 24,15$)$ a nie 25,15 , jak podano $w$ wspomnianym artykule).

Tekst stwierdza, że oddział kapłański noszący imię Happicceca kapłana z czasów Dawida czy Nehemiasza? - osiedlił się w Nazaret, że więc miasto to istniało około r. 70 po Chr., że istnieć musiało w epoce N. T.

Z napisu obecnie odnalezionego dowiadujemy się także, jaka była właściwa pisownia nazwy miasta. Z greckiej formy ,Nazaret” należałoby - wnioskować, że Nazaret pisano w hebrajskim przez zajin, lecz teraz jest 
rzeczą pewną; że pisano przez cade. Wobec tego również etymologia nazwy staje się językowo jaśniejsza i pewniejsza. Nazaret wywodzi się od rdzenia ,nacar" = czuwać, pełni straż. Miasteczko to, dość wysolro położone w pobliżu głównego traktu, było niejako ,strażnicą”. Etymologia dawna wywodząca nazwę od ,necer" = latorośl, nowy pęd roślinny, operuje za wiele alegorią, której stosowania w toponomastyce dotąd nie stwierdzono.

Kraków

A. $K$.

\section{Ks. Wiadyslaw Palubicki, SVD Lublin}

\section{PISMO ŚW. W KATECHEZIE MISYJNEJ}

Wyznanie Psalmisty: Słowa Twoje [BożeI sa pochodnia dla nóg moich i światłościa dla moich ścieżek (Ps 119, 105) stały się dewizą życiową niemal dla wszystkich głosicieli „Dobrej Nowiny”. Już w pierwszych wiekach zwracano uwage na to, żeby Słowo Boże było dostępne dla ludzi wszystkich ras i kultur. Dlatego też tłumaczono Pismo św. na języki tubylcze. Świadczą o tym już tak wcześnie dokonane przekłady Biblii jak: łacińskie, koptyckie, syryjskie, egipskie, etiopskie, armeńskie, georgijskie, arabskie, gockie i słowiańskie. Głosiciele Ewangelii rozumieli dobrze, że Pismo św. jest częstokroć najlepszym misjonarzem ${ }^{1}$ i nierzadkie były wypadki, kiedy to czytanie Biblii przyczyniło się prędzej do nawrócenia niż płomienne kazanie wytrawnego kaznodziei.

W późniejszych jednak stuleciach Pismo św. zeszło przez jakiś czas ná dalszy plan w katechezie misyjnej. Miejsce Biblii zajał katechizm, a Pismo św. służyło tylko do wyjaśnienia niektórych partii katechizmu, względnie do udokumentowania niektórych twierdzeń teologicznych.

Dopiero pod koniec Średniowiecza i w czasach nowożytnych zaczyna się ponownie rozwijảc w krajach misjonowanych ruch biblijny. Jest to zasługa głównie samych misjonarzy, zarówno protestanckich jak i katolickich.

\section{Zasługi protestantów}

Jednym z pierwszych misjonarzy rozpowszechniajacych Pismo św. na terenie misji był B. Zi e g e n ba $1 \mathrm{~g}$. W latach 1708-1715 dokonał on przekładu całego Nowego Testamentu na język tamilski ${ }^{2}$. W Chinach najwięcej propagowali Pismo św. K. Guetzlaff i J. Schereschevski, którzy przełożyli całe Pismo św. na szereg dialektów miejscowych. Na terenie Afryki to samo uczynili

1 A. Lehmann, Die Hl. Schrift in der Missionen und in den jungen Kirchen, RGG ${ }^{3}, 1152$.

2 Por. R. Steine r, Missionsuebersetzungen, EK, I, 488. 